ЕКОНОМІЧНИЙ ЗМІСТ ТА СУБСИСТЕМИ

ОРГАНІЗАЦІЙНО-ІНФОРМАЦІЙНОГО ЗАБЕЗПЕЧЕННЯ АНТИКРИЗОВОГО УПРАВЛІННЯ АГРОФОРМУВАННЯМИ

\title{
ECONOMIC CONTENT AND SUBSYSTEMS OF ORGANIZATION AND INFORMATION SUPPORT FOR ANTI-CRISIS MANAGEMENT OF AGRICULTURAL ENTERPRISES
}

УДК 658.012:338.242

DOI: https://doi.org/10.32843/bses.48-54

\section{Шинькович А.B.}

аспірант кафедри

бухгалтерського обліку

Вінницький національний

аграрний університет

\section{Shinkovich Andriy}

Vinnytsia National Agrarian University

\begin{abstract}
y cmammi з'ясовано економічний зміст організаційно-інорормаційного забезпечення антикризового управління агрофрормувань, визначено принципи, фрункції та основні його властивості, виявлено особливості його формування в агроорормуваннях, встановлено завдання та обгрунтовано склад субсистем організаційно-інформаційного забезпечення антикризового управління агрофрормуваннями, окреслено інструментарій та алгоритм, виявлено проблеми та переваги організаційно-інформаційного забезпечення антикризового управління агроформуваннями. Організаційно-інформачійне забезпечення антикризового управління агроформуваннями створює можливості для: своєчасного виявлення ризиків та загроз для агрофрормувань; здійснення контролю за витратами та прибутками агрофрормувань; оперативного інсрормування керівництва про всі кризові процеси та явища, що відбуваються в агрофрормуванні та мають вплив на його фуннкціонування; забезпечення деталізованою інформацією та аналітичним аналізом; виявлення оптимуму для розподілу всіх ресурсів агрофрормування; моделювання різних сценаріїв розвитку агроформування за кризових процесів. Ключевые слова: організаційно-інформачійне забезпечення, агрофрормування, антикризове управління, економічний зміст.
\end{abstract}

В статье выяснено экономическое содержание организационно-инорормационного обеспечения антикризисного управления агроорормированиями, определены принципы, фрункции и основные его свойства, выявлены особенности его фрормирования в агрофрормированиях, установлено задание и обоснован состав субсистем организационно-инорормационного обеспечения антикризисного управления агроформированиями, обозначены инструментарий и алгоритм, выявлены проблемь и преимущества организационно-инорормационного обеспечения антикризисного управления агросрормированиями. Организационно-инсрормационное обеспечение антикризисного управления агроформированиями создает возможности для: своевременного выявления рисков и угроз для агрофоомирований; осуществления контроля за расходами и доходами агрофрормирований; оперативного информирования руководства обо всех кризисных процессах и явлениях, происходящих в агроформировании и влияющих на его функционирование; обеспечения детализированной информацией и аналитическим анализом; выявления оптимума для распределения всех ресурсов агроформирования; моделирования различных сценариев развития агросрормирования при кризисных процессах.

Ключевые слова: организационно-инсрормационное обеспечение, агроформирование, антикризисное управление, экономическое содержание.

The article describes the economic content of organizational and information support of the crisis management of agroformations, identifies the principles, functions and basic properties of it, identifies the peculiarities of its formation in agroformations, establishes the tasks and substantiates the composition of subsystems of organizational and information support of crisis management of agricultural formations, outlines tools and algorithms problems and advantages of organizational and information support of the crisis management of agroformations have been identified. In particular, it is justified that compliance with the complexity of subsystems will facilitate timely receipt and processing of necessary and reliable information to the management of agro-formations and its individual structural units. Organizational and informational support of crisis management of agricultural formations creates opportunities for: timely identification of risks and threats of agricultural formations; control of costs and profits of agricultural companies; promptly informing management about all crisis processes and phenomena that occur in agro-formation and have an impact on its functioning; providing detailed information and analytical analysis; identifying the optimum for the distribution of all resources of agricultural formation; modeling of different scenarios of agroformation development in crisis processes. At the same time, it was noted that high-quality and timely organizational and informational support of the crisis management of agroformations allows: to define precisely the purpose and formulate the tasks of the crisis management of agricultural formations; to establish a logical sequence of the procedure of development and adoption of necessary current and strategic management anti-crisis solutions; to formulate reasonable contours regarding strategic forecasts, scenarios, programs, plans of crisis management of agroformations; to develop an optimal technology for evaluating the effectiveness of organizational and information support of the crisis management of agroformations, which will facilitate the proper control over the accuracy, quality, timeliness of the necessary preventive measures.

Key words: organizational-information support, agro-formation, crisis management, economic content.

Постановка проблеми. Будь-яке агроформування незалежно від масштабу чи галузі свого виробництва підпадає під вплив руйнівних процесів, що негативно впливає на його конкурентоспроможність, призводить до фрінансових втрат та навіть до банкрутства. При цьому параметри конкурентного середовища, в якому фрункціонують агроформування, характеризуються динамічністю, що зумовлює ухвалення управлінських рішень в умовах загроз та невизначеності та висуває нові вимоги до субсистем організаційноінфрормаційного забезпечення їхнього антикризового управління. Адже нові технології, які нині активно використовуються для збору, систематизації, аналітичної обробки, планування, прогнозування, ухвалення оперативних та стратегічних рішень, не повністю враховують особливості фрункціонування агроформувань, неефективні і не об'єднані в комплексну систему методів, підходів, інструментів, засобів, тому вони не набули 
поширення та визнання у спеціалістів і науковців аграрної сорери. Немає єдиного розуміння економічного змісту організаційно-інформаційного забезпечення антикризового управління агроорормуваннями, складу його субсистем, напрямів розвитку, відсутній загальноприйнятий термінологічно поняттєвий апарат, що зумовлює необхідність уточнення сутнісних та змістових аспектів і базових підходів до вирішення означених питань та набуває першорядного значення. Усе це переконує щодо актуальності поставлених завдань та підтверджує необхідність цього дослідження.

Аналіз останніх досліджень та публікацій. Теоретичною платформою щодо сутнісних та змістових аспектів фрормування організаційно-інорормаційного забезпечення антикризового управління агроформуваннями та їх субсистемами стали вагомі наукові розробки таких відомих учених, як: І. Ансооро, Е. Альтман, У. Бівер, І. Бланк, Л. Вдовенко, О. Гудзь, О. Гук, Л. Гуцаленко, П. Друкер, Г. Калетник, К. Ларіонова, В. Луцяк, В. Мазур, О. Мельник, В. Плескач, Н. Правдюк, Т. Пуліна, І. Свиноус, Л. Ситник, П. Стецюк, А. Томпсон, О. Терещенко, А. Шегда, А. Штангрет, Л. Чорна, О. Ястремська та ін. Високо оцінюючи їхні наукові здобутки, відзначимо, що низка питань стосовно визначення економічного змісту та субсистем організаційно-інорормаційного забезпечення антикризового управління агроформуваннями залишаються не досить опрацьованими.

Постановка завдання. Метою статті є уточнення економічного змісту організаційно-інфрормаційного забезпечення антикризового управління агрофрормуваннями, визначення принципів, фрункцій та основних його властивостей, виявлення особливостей його фрормування в агрофрормуваннях, встановлення завдань та обґрунтування складу субсистем організаційно-інфрормаційного забезпечення антикризового управління агрофрормуваннями, окреслення інструментарію та алгоритму, виявлення проблем та переваг організаційно-інфрормаційного забезпечення антикризового управління агроформуваннями.

Виклад основного матеріалу. Конкурентне середовище в кризових умовах сьогодення характеризується складними деформаційними процесами, які генерують низку додаткових проблем, загроз та ризиків для успішного сталого розвитку агроформувань. Безповоротність помилкових платежів, товариства-одноденки, шахрайські угоди, недобросовісність постачальників та персоналу, рейдерські захоплення, сумнівна дебіторська заборгованість, кібератаки - це неповний перелік щоденних проблем, які необхідно постійно вирішувати агрофрормуванням у межах антикризового управління і які без якісної та своєчасної організаційно-інфрормаційної підтримки ухвалення управлінських рішень вирішити неможливо. Вихід вітчизняних агрофрормувань на міжнародні аграрні ринки, поглиблення глобалізаційних процесів та загострення конкурентної боротьби ще більше актуалізують необхідність фрормування організаційно-інформаційного забезпечення антикризового управління агроформуваннями на якісно новій основі із застосуванням сучасного інструментарію та цисррових технологій. Антикризове управління, що здійснюється в умовах загроз і невизначеності фрункціонування агроформувань, вимагає виваженості та особливого організаційно-інформаційного забезпечення на підґрунті високоорганізованого організаційного дизайну, яке сполучає організаційні взаємодії, інорормаційно-комунікаційні ланцюги, телекомунікаційне, комп'ютерне, програмне забезпечення, компетентності, ГІС, нейро, хмарні та захисні технології тощо. Оскільки для ухвалення обґрунтованих рішень доцільно своєчасно та об'єктивно аналізувати складні деформаційні процеси і явища та розробляти різні стратегічні сценарії розвитку агрофрормування й антикризового управління, то відповідальних працівників необхідно постійно забезпечувати аналітичною та прогностичною інформацією для розроблення та прийняття найбільш оптимальних управлінських антикризових рішень і заходів.

Для визначення економічного змісту та субсистем організаційно-інформаційного забезпечення антикризового управління агрофрормуваннями спочатку розглянемо, як трактуються поняття «організаційне та інформаційне забезпечення». У наукових публікаціях знаходимо різні підходи до тлумачення поняття «організаційне забезпечення". Так, $€$. Моісенко вважає, що «організаційне забезпечення - це сукупність документів, що встановлюють організаційну структуру, права та обов'язки користувачів та експлуатаційного персоналу" [6]. В. Андрєєва визнає, що «організаційне забезпечення - положення, інструкції, накази, кваліфікаційні вимоги та інші документи, що регламентують організаційну структуру роботи системи і їхню взаємодію з комплексом засобів системи [1, с. 78]. Г. Колесніков стверджує, що «організаційне забезпечення - це складний комплекс стійких, свідомо створених зв'язків та взаємодії елементів виробничо-управлінської системи, які виникають у процесі фрункціонування та розвитку підприємства" [4]. В. Гладкий переконує, що «організаційне забезпечення - це організація робіт та заходів, створення структури, що забезпечує нормальну експлуатацію системи підприємства" [2, с. 68]. Г. Демченко обґрунтовує, що «організаційне забезпечення - це система процесів і процедур для здійснення сталого функціонування підприємства згідно з одержаною стратегією і поставленими цілями, яка забезпечує впорядкованість елементів і відносин за рахунок організації взаємозв'язку між підрозділами підприємства та забезпечення їх необхідними ресурсами" [3, с. 66]. 
Також у наукових публікаціях знаходимо й різні підходи до тлумачення поняття інформаційного забезпечення. Так, О. Кузьмін стверджує, що «інформаційне забезпечення - це система якісних і кількісних показників, що характеризують рівень задоволення суб'єктів управлінської діяльності управлінською інфрормацією та інформаційним технологіями з метою реалізації інфрормаційною системою встановлених цілей та завдань" [5, с. 64]. Л. Стецюк вважає, що «інорормаційне забезпечення - це система організаційних заходів і технічних засобів для одержання, обробки, передачі та зберігання інформації, створена з метою забезпечення потреб користувачів інорормацією для ефрективного управління господарською діяльністю підприємства" [7, с. 138]. Н. Тарасенка обґрунтовує, що «інфрормаційне забезпечення - сукупність інфрормаційних ресурсів та методів їх організації, що необхідні і придатні для реалізації аналітичних та управлінських процедур, які забезпечують господарсько-фрінансову діяльність підприємства" [8, с. 29]. Н. Хахонова переконана, що «інформаційне забезпечення - це складний динамічний комплексний процес задоволення інорормаційних потреб керівників, що виконує фрункції раціоналізації діяльності" [9, с. 232].

Таким чином, опираючись на означене, можемо визначити, що організаційно-інформаційне забезпечення антикризового управління агрофрормуваннями - це сукупність взаємопов'язаних субсистем щодо організаційної, інфрормаційної, комунікаційної, програмної, нормативно-регламентної та обліково-аналітичної підтримки процедури розроблення та ухвалення обґрунтованих управлінських рішень та імплементації антикризових заходів задля досягнення мети антикризового управління агрофрормуваннями.

Відповідно до такого визначення, фрундаментальною основою організаційно-інфрормаційного забезпечення антикризового управління агрофрормуваннями $€$ першочергове встановлення внутрішніх організаційних ланцюгів, зв'язків і залежностей між різними контактними аудиторіями та окремими структурними одиницями і побудова на цій платорормі субсистем, які би підтримували процедури розроблення та ухвалення обґрунтованих управлінських рішень та імплементації антикризових заходів задля досягнення мети антикризового управління агрофрормуваннями. Тобто організаційно-інформаційне забезпечення антикризового управління агрофрормуваннями повинно мати універсальний характер, оскільки організаційне забезпечення вимагає компетентнісної та інфрормаційної підтримки для розроблення та ухвалення обґрунтованих управлінських рішень та імплементації антикризових заходів.

У загальному розумінні економічний зміст організаційно-інформаційного забезпечення анти- кризового управління агрофрормуваннями зосереджений у динамічній здатності фрормувати інфрормаційні, комунікаційні і компетентнісні можливості та організаційні передумови для підтримки процесу розроблення та ухвалення обґрунтованих управлінських рішень та імплементації антикризових заходів задля досягнення мети антикризового управління агрофрормуваннями.

Отже, метою організаційно-інфрормаційного забезпечення антикризового управління агрофрормуваннями слід вважати динамічну здатність орормувати інорормаційні, комунікаційні і компетентнісні можливості та організаційні передумови в органічній логічній їх єдності для підтримки управлінських рішень та імплементації антикризових заходів задля досягнення мети антикризового управління агрофрормуваннями щодо захисту від зовнішніх і внутрішніх загроз його діяльності та забезпечення його стабільного розвитку за несприятливого впливу різноманітних чинників.

Під час орормування організаційно-інорормаційного забезпечення антикризового управління агрофрормуваннями доцільно дотримуватися таких ключових принципів: еволюційності; єдності організаційного та інформаційно-комунікаційного процесів; адекватності; ієрархічності; системності; оперативності; самоорганізації; точності; організаційного моделювання; пропорційності; інфрормаційної повноти; безперервності; інноваційності; циклічності; інтерактивності; узгодженості; стислості; оптимальності. Перелік принципів фрормування організаційноінфрормаційного забезпечення антикризового управління агрофрормуваннями не є вичерпним, його за необхідності можна доповнювати.

Можна виділити ключові функції організаційноінфрормаційного забезпечення антикризового управління агрофрормуваннями: організаційну; фрункцію зв'язку із зовнішнім середовищем; комунікаційну; фрункцію підтримки зв'язків між структурними одиницями та різними контактними аудиторіями; інорормаційну; захисну; превентивну; програмної підтримки; нормативно-регламентну; аналітико-прогностичну; обліково-аналітичну.

Слід зауважити, що важливою особливістю фрормування організаційно-інфрормаційного забезпечення антикризового управління агрофрормуваннями $є$ підтримка якості ухвалених рішень в умовах загроз, невизначеності й ризику. Іншими особливостями можна вважати:

- широкий спектр ризиків та загроз;

- необхідність використання нових організаційних систем та систем землеробства;

- врахування просторово-часових, агрокліматичних та інорормаційних обмежень;

- доцільність використання ГІС, нейротехнологій, засобів дистанційного зондування ґрунту;

- вплив біологічних об'єктів на результати діяльності агрофрормувань; 
- безперервність та циклічність операційних процесів, які важко фрормалізувати;

- значну кількість показників діяльності, які необхідно контролювати;

- просторову розосередженість виробництва;

- різноманітність операцій у сільськогосподарському виробництві;

- розроблення громіздких технологічних карт;

- необхідність використання для прогнозування різноманітних сценаріїв нелінійного інструментарію штучних нейронних мереж;

- диференціацію агрофрормувань за обсягами, ресурсним забезпеченням, організаційними структурами, компетентностями, іноро-комунікаційними можливостями;

- неповноту інорормації та непорівнюваність характеристик об'єктів антикризового управління.

Ключовими завданнями організаційно-інорормаційного забезпечення антикризового управління агрофрормувань $є$ :

- накопичення та узагальнення об'єктивної інорормації щодо зовнішніх загроз, внутрішніх ризиків;

- захист інорормації від несанкціонованого використання;

- оцінка стану ризикозахищеності агрофрормування;

- забезпечення віддаленого дистанційного доступу керівництву до інфрормації та бази геоданих із використанням хмарних технологій, Webархітектури, мережі Інтернет;

- постійний моніторинг та аналіз фрінансово-економічного стану та індикаторів ефективності агроформування з врахуванням галузевих особливостей;

- мінімізація ризику втрати інорормації;

- використання багатомірного аналізу для виявлення посягань на інорормаційну та економічну безпеку агроформування;

- оперативність надання необхідної інорормації усім структурним одиницям та контактним аудиторіям у задані моменти часу;

- виявлення каналів витоку інорормації та ідентифікація передумов надзвичайних подій;

- перевірка надійності бізнес-партнерів, персоналу, постачальників, клієнтів задля мінімізації ділових ризиків;

- розроблення технологічних карт;

- оцінка іміджу агроформування та протистояння «чорному PR";

- підвищення оперативності та якості аналітичної інфрормації для ухвалення антикризових рішень;

- запобігання дублюванню функцій менеджерів та структурних одиниць;

- моделювання та прогнозування різних сценаріїв розвитку агроформування;

- пошук шляхів оптимізації інфрокомунікаційних ланцюгів та використання ресурсів агрофрормування;
- скорочення часу на ухвалення рішень, координацію і погодження заходів;

- верифікація просторово-координованих даних;

- підготовка документації для аналітичної підтримки процесу ухвалення управлінських антикризових рішень;

- підвищення ефрективності організаційної структури агрофрормування та його організаційної поведінки.

Формування складу субсистем організаційноінфрормаційного забезпечення антикризового управління агроорормуваннями має відбуватися із врахуванням таких властивостей: системності, доступності, цілісності та єдності, зорієнтованості, сумісності, комплексності, портативності, дисреренціації, здатності до інтеграції, індивідуалізації, масштабності, детермінації, еластичності та превентивності.

Зважаючи на означене, можна стверджувати, що організаційно-інфрормаційне забезпечення антикризового управління агрофрормуваннями має складатися із взаємопов'язаних між собою субсистем. До таких субсистем організаційно-інформаційного забезпечення антикризового управління агрофрормуваннями слід долучити: організаційну, інорормаційну, комунікаційну, програмної підтримки, нормативно-регламентну, обліково-аналітичну.

Кожна субсистема організаційно-інформаційного забезпечення антикризового управління агрофрормуваннями має включати засоби, ланцюги, методи та інструменти організації і передачі інорормаційних потоків між структурними одиницями усіх ієрархічних рівнів та усіма контактними аудиторіями агрофрормування. Усі субсистеми організаційно-інформаційного забезпечення агроформувань повинні підтримуватись сучасними інорормаційними технологіями та комунікаційними ланцюгами.

Дотримання комплексності субсистем під час фрормування складових частин організаційноінформаційного забезпечення антикризового управління агроформуваннями сприятиме своєчасному надходженню та обробці необхідної та достовірної інформації до керівництва агроформувань та окремих його структурних одиниць, а також виходу потрібних даних за його межі щодо діяльності агроорормування та змін, які відбулися.

Організаційно-інфрормаційне забезпечення антикризового управління агроформуваннями має підтримуватися відповідним інструментарієм: системою управління інформаційними базами даних та базами геоданих, Business intelligence, ГIC-технологіями, технологіями ETL, нейротехнологіями, Data Warehouse, експертними системами, ERP (Enterprise Resource Planning), базою відповідних знань, Data Mining, базою відповідних економіко-математичних моделей для прогнозування та моделювання, CALS-технологіями. 
Алгоритм використання організаційно-інфрормаційного забезпечення антикризового управління агрофрормуваннями може бути таким: ідентифрікація стану фрінансово-економічних та кризових процесів агроформувань; виявлення проблеми; постановка задачі; діагностика наявних загроз, ризиків, можливостей; аналіз організаційної та інорормаційно-комунікаційної архітектури; проектування, побудова та перетворення інорормаційної бази даних; проектування організаційної структури та комунікаційних ланцюгів; оптимізація складових субсистем; розроблення сценаріїв стратегічного розвитку організаційно-інорормаційного забезпечення антикризового управління агроформуваннями; документування необхідних процесів; обґрунтування інструментарію тактичної гнучкості організаційно-інформаційного забезпечення антикризового управління агрофрормуваннями; здійснення тестування; відповідне навчання персоналу; прогнозування результативності організаційно-інорормаційного забезпечення антикризового управління агроформуваннями; впровадження ухвалених управлінських антикризових рішень та заходів; підтримка та супровід.

Організаційно-інформаційне забезпечення антикризового управління агроорормуваннями не може вважатися результативним, якщо вигоди від його використання відчутно не перевищують витрат на його формування. Результативне організаційно-інформаційне забезпечення антикризового управління агроформуваннями - це не обов'язково таке, що опрацьовує великий інфрормаційний масив даних із найвищою точністю і швидкістю. Результативне організаційно-інформаційне забезпечення антикризового управління агроформуваннями - це таке, яке якісно опрацьовує достатню кількість інформаційних даних, що необхідні для ефрективного антикризового управління за мінімальних витрат. Зауважимо, що вартість експлуатації організаційно-інфрормаційного забезпечення антикризового управління агрофрормуваннями може значно бути вищою за оплату праці персоналу і вартість технологічного обладнання.

Ключовою проблемою, пов'язаною із використанням організаційно-інформаційного забезпечення антикризового управління агрофрормуваннями $€$ надмірність інфрормаційного шуму, що помітно ускладнює процес ухвалення антикризових рішень.

Ключовими перевагами використання визначених субсистем організаційно-інформаційного забезпечення антикризового управління агроформувань Є:

- підвищення ступеня керованості в умовах кризи;

- зниження впливу суб'єктивного чинника;

- скорочення паперових носіїв;

- підвищення оперативності і достовірності інфрормаційних даних;

- зниження витрат на антикризове управління;
- оптимізація процедур моніторингу, аналізу, обліку, контролю, прогнозування та моделювання;

- забезпечення прозорості інфрормації та зниження її асиметрії;

- можливість нарощення компетентностей та конкурентних переваг агрофрормувань.

Зауважимо, що організаційно-інформаційне забезпечення антикризового управління агроформувань ефективно проявляється за:

- наявності відповідних організаційних, інорормаційно-комунікаційних та аналітичних компетентностей у спеціалістів агрофрормувань;

- чіткого окреслення відповідних методів, форм, інструментарію, засобів для досягнення його оперативності, об'єктивності під час розроблення та ухвалення оптимальних управлінських антикризових рішень.

Висновки 3 проведеного дослідження. У статті з'ясовано економічний зміст організаційно-інформаційного забезпечення антикризового управління агроформуваннями, визначено принципи, фрункції та основні його властивості, виявлено особливості його фрормування в агрофрормуваннях, встановлено завдання та обґрунтовано склад субсистем організаційно-інорормаційного забезпечення антикризового управління агроформуваннями, окреслено інструментарій та алгоритм, виявлено проблеми та переваги організаційно-інформаційного забезпечення антикризового управління агроформуваннями. Зокрема, обґрунтовано, що дотримання комплексності субсистем сприятиме своєчасному надходженню та обробці необхідної та достовірної інорормації до керівництва агросормувань та окремих його структурних одиниць.

Організаційно-інфрормаційне забезпечення антикризового управління агроформуваннями створює можливості для: своєчасного виявлення ризиків та загроз для агрофрормувань; здійснення контролю за витратами та прибутками агроформувань; оперативного інорормування керівництва про усі кризові процеси та явища, що відбуваються в агрофрормуванні та мають вплив на його фрункціонування; забезпечення деталізованою інформацією та аналітичним аналізом; виявлення оптимуму для розподілу усіх ресурсів агрофрормування; моделювання різних сценаріїв розвитку агроформування за кризових процесів. Водночас відзначено, що якісне та своєчасне організаційно-інформаційне забезпечення антикризового управління агрофрормуваннями дозволяє: точно визначити мету та сорормулювати завдання антикризового управління агрофрормувань; встановити логічну послідовність процедури розроблення й ухвалення необхідних поточних і стратегічних управлінських антикризових рішень; сформувати обґрунтовані контури щодо стратегічних прогнозів, сценаріїв, програм, планів антикризового 
управління агроформуваннями; розробити оптимальну технологію оцінювання результативності організаційно-інорормаційного забезпечення антикризового управління агрофрормуваннями, що сприятиме здійсненню належного контролю за точністю, якістю, своєчасністю необхідних превентивних заходів.

\section{БІБЛІОГРАФІЧНИЙ СПИСОК:}

1. Андреева В.И. Организационное обеспечение работы с кадровой документацией. Справочник кадровика. 2009. № 3. С. 77-85.

2. Гладкий В.И. Кадастровые работы в городах. Новосибирск: Наука, 1998. 150 с.

3. Демченко Г.В. Розвиток теоретичних засад організаційного забезпечення інноваційної діяльності підприємства. Економічний аналіз. 2015. № 2. С. 63-68.

4. Колесніков Г.О. Міжнародний словник. URL: http://ebooktime.net/book_294_glava_18_Об'єкти_ впливу_html (дата звернення: 19.03.2018).

5. Кузьмін О.Є. Формування і використання інорормаційної системи управління економічним розвитком підприємства: монографрія. Львів: Вид-во Нац. ун-ту „Львівська політехніка”, 2006. 368 с.

6. Моисеенко Е.В. Информационные технологии в экономике. URL: http://abc.vvsu.ru/Books/up_ inform_tehnol_v_ekon/page0009.asp10 (дата звернення: 10.04.2019).

7. Стецюк Л.С. Оцінка стану інфрормаційного забезпечення аналізу господарської діяльності підприємства. Облік і фрінанси. 2014. № 3(65). C. 136-141.

8. Тарасенко Н.В. Економічний аналіз: навч. Посібник. Львів: Новий Світ 2000, 2003. 316 с.

9. Хахонова Н.Н. Теоретико-методологическое исследование категории „учетно-аналитическая система" управления коммерческой организации. Фундаментальные исследования. 2012. № 9. С. 231-234.

\section{REFERENCES:}

1. Andreeva V.I. (2009) Organizatsionnoe obespechenie rabotyi s kadrovoy dokumentatsiey [Organizational support for work with personnel documentation]. Spravochnik kadrovika. no. 3. pp. 77-85. (in Russian)

2. Gladkiy V.I. (1998) Kadastrovyie rabotyi v gorodah [Cadastral works in cities]. Novosibirsk: Nauka. 150 p. (in Russian)

3. Demchenko G.V. (2015) Rozvitok teoretichnih zasad organizatsiynogo zabezpechennya innovatsiynoï diyalnosti pidpriemstva [Development of theoretical foundations of organizational support of enterprise innovation activity]. Ekonomichniy analiz. no. 2. pp. 63-68. (in Ukrainian)

4. Kolesnikov G.O. Mijnarodniy slovnik [International dictionary]. Available at: http://ebooktime.net/book 294 glava_18_Ob'€kti_vplivu_html (accessed 19.03.2019).

5. Kuzmin O. $\bar{Y}$ e. (2006) Formuvannya i vikoristannya informatsiynoï sistemi upravlinnya ekonomichnim rozvitkom pidpriemstva [Formation and use of information system for managing the economic development of the enterprise]: monografiya. Lviv: Vid-vo Nats. un-tu "Lvivska politehnika”. 368 p. (in Ukrainian)

6. Moiseenko E.V. Informatsionnyie tehnologii v ekonomike [Information Technology in Economics]. Available at: http://abc.vvsu.ru /Books/up_ inform_tehnol_ v_ekon/page0009.asp 10 (accessed 10.04.2019).

7. Stetsyuk L.S. (2014) Otsinka stanu informatsiynogo zabezpechennya analizu gospodarskoï diyalnosti pidpriemstva [Assessment of the state of information support for the analysis of economic activity of the enterprise]. Oblik i finansi. no. 3 (65). pp. 136-141. (in Ukrainian)

8. Tarasenko N.V. (2003) Ekonomichniy analiz [Economic analysis]: navch. posibnik. Lviv: Noviy Svit 2000. 316 p. (in Ukrainian)

9. Hahonova N.N. (2012) Teoretiko-metodologicheskoe issledovanie kategorii „uchetno-analiticheskaya sistema" upravleniya kommercheskoy organizatsii [Theoretical and methodological study of the category "accounting and analytical system" of management of a commercial organization]. Fundamentalnyie issledovaniya. no. 9. pp. 231-234. (in Russian) 